\title{
The Impact of Economic Policy Uncertainty on Capital Structure: Evidence from Russia
}

Brigitte Granville

PhD, Professor

ORCID

E-mail: b.granville@qmul.ac.uk

Queen Mary University of London, London, the United Kingdom

\section{Roman Matousek}

ORCID

E-mail: rom.matousek@gmail.com

Queen Mary University of London, London, the United Kingdom

\section{Egor Sokolov}

Business Analyst

$\underline{\text { ORCID }}$

E-mail: sokolovyegor@gmail.com

McKinsey \& Company, Moscow, Russia

Journal of Corporate Finance Research, Vol. 13, No. 4, pp. 7-19 (2019)

DOI: https://doi.org/10.17323/j.jcfr.2073-0438.13.4.2019.7-19

Received 15 September 2019 | Peer-reviewed 1 November 2019 | Accepted 3 December 2019 


\section{The Impact of Economic Policy Uncertainty on Capital Structure: Evidence from Russia}

\section{Abstract}

This paper is a study of the influence of economic policy uncertainty on the capital structure of companies operating in the Russian market. The sample size is particularly notable (over 16,000 companies and 230,000 observations are included) insofar as previous studies have invariably used smaller selections due to the complexities of data processing. Several hypotheses are proposed and treated which concern the interrelations between company debt policies and the status of individual, sectoral, or industry relevant commercial activity, where the constant threat of economic uncertainty due to political or other external machinations affects the market.

This research paper examines the following capital structure determinants: profitability, asset structure, company size, tax shield, non-debt tax shield, growth opportunity, and risk. The following methods are applied to test a series of nine hypotheses proposed as the most salient indicators of the present state of academic consensus: the Pool model (Pool), the fixed effect model (FE), and the random effect model (RE). In this context, the influence of economic uncertainty on the status of different debt types in 16,882 Russian companies between 2000 and 2017 was studied using the economic policy uncertainty index calculated in 2012.

The results serve to confirm many of the extant hypotheses in the academic literature in the area of capital structural evaluation. For example, it is immediately apparent that the influence of uncertainty is of less significance for large companies as regards all types of debt (joint, short-term and long-term), due to their greater stability and lower risks for creditors. Among other conclusions, it is confirmed that as long as serious government participation is characteristic of the Russian banking system, the efficacy of the debt financing system is not equal for all sectors, and those sectors which are of strategic importance for the state are particularly resilient in troubled economic periods. However, interestingly, in the case of a short-term debt leverage such influence does not materialise.

From a theoretical point of view this paper will be useful for researchers studying the fluctuating market conditions of developing or transitional markets (the large sample size will make this study particularly attractive for further evaluation at all levels of academic analysis). An understanding of the multivariate interrelations described in this paper may also be useful to company managers and investors who will gain insight into the consequences of fluctuations in levels of economic uncertainty for different types of companies.

Keywords: economic policy uncertainty index, capital structure

JEL classification: G23, G28, G32, P34 


\section{Introduction}

A seminal 1958 paper by Modigliani and Miller [1] initiated an endless dispute about the factors that affect companies' funding decisions. A large number of papers have since investigated and clearly revealed the links that help to understand the role of the factors which define a company's debt load, which include profitability, company size, effective tax rate, company growth, asset tangibility, non-debt tax shield, etc. (see for example [2] and [3]). Nevertheless, the non-specific factors that may affect company debts irrespective of any economic and policy uncertainty only came to attention rather recently [4]; [5]. In terms of analysing the influence of the economic environment on capital structure, the most recent studies ([6]; [7]) include profitability volatility factors in their models as business risks, and have considered inflation uncertainty, interest rates uncertainty, and differences in analytical forecasts as macroeconomic risks. However, even with all these factors considered, the studies have addressed only some aspects of uncertainty.

In this paper, in order to obtain the most comprehensive assessment of the economic uncertainty effect we propose to use the index of economic policy uncertainty proposed by Baker et al. [8]. This index represents the frequency with which articles which discuss economic policy uncertainty are published in mass media. This measure of uncertainty differs from other measures in that it aggregates all possible factors discussed in mass media coverage of economic and political issues, rather than being comprised of separate elements (e.g. uncertainty of inflation, interest rates etc.)

As far as political uncertainty is concerned, essentially, companies perform activities in the business environment which have been defined by national policies, regulations and legislation. Political decisions are taken after several approval stages and implementation of a new policy takes time, which generates political uncertainty in the business environment. This uncertainty may be elevated in cases of disagreement between politicians or government entities. Uncertainty about future events has been seen to influence the behaviour of economic operators [9]; [10].

The research objective of this study is to contribute to current research on economic and policy uncertainty in several ways. First, we investigate the influence of economic policy uncertainty on the capital structure of companies within the Russian market. This includes not only debt, but also the levels and terms of short-term and long-term debt. It is well-recognised that frequent government interventions in market mechanisms are typical properties of emerging and less developed economies (e.g. see [11]; [12]), and the Russian financial market is no exception. One third of the Russian banking system is state-owned. Such a share of the state participation raises the question of whether or not the Russian government influences the direction of funds to certain companies when necessary. This is not a policy limited to Russia, but has been witnessed in many Central and Eastern European countries in the 1990s. By using an extensive data set that includes companies within 'sectors of strategic importance', we intend to investigate the degree to which affiliation with a certain type of activity reduces the influence of uncertainty.

\section{Review of Literature}

The majority of research in the field focuses on the study of developed markets of the Western countries and USA [13] [14]. This is logical, as the maturity and diversity of financial markets, good regulation, and the relatively high transparency of activity of companies in developed markets.

Over recent years, emerging markets have been attracting researchers. Questions had been raised as to whether emerging markets were conceptually different in kind to developed ones, had their own specific features, or whether the theoretical concepts used to analyse companies in developed markets may be applied to analyse companies from emerging markets.

On the basis of undertaken research studies [15]; [16]; [17]; [18]; [19]; [20], one may note that emerging markets have certain characteristic properties which influence the companies' financing strategies. Among them are having limited access to capital, high information asymmetry and agency costs, high macroeconomic risks for investors, an ineffective corporate organisation of companies (a large share of state participation, a large share of property owned by one shareholder), and a low level of corporate management.

Thus, the financial markets in emerging countries differ significantly from the markets of developed countries. This results in difficulties in forecasting and long-term planning due to ineffective market functioning and the high risks involved.

At the same, it was proven that the same traditional determinants are generally significant in emerging markets such as profitability, asset structure, company size, and the presence of a tax shield [21]; [22]; [16]; [23]; [24]. However, just as in other research, the direction of influence of some factors on the capital structure may differ depending on the study. This may be due to the fact that not every company can take decisions on the basis of the same mechanism by virtue of their individual characteristics [25].

On account of the market-specific character of companies, some authors put an emphasis on various institutional characteristic properties. For example, the following authors: [21]; [22]; [25]; [26] reveal that state participation in company capital has a positive effect upon the company debt load. This stems from the fact that nearly half of the Russian banking system is state owned, and as a result the banking business represents a political tool for the distribution of financial resources [27]; [28]. Consequently, partly state-owned companies have better access to debt financing in comparison to non-state-owned companies. It has also been pointed out that in the Russian market, companies 
tend to have more debts if an oligarch is one of their shareholders [26]. Oligarchs can use their close connections with senior state officials in order to obtain financial assistance by means of credits from state banks [29].

Finally, in emerging markets, a positive impact of the level of development of the banking and legal system and the stock market has been highlighted, alongside a negative impact vis-á-vis the levels of corruption.

Initially, when analysing the influence of risks on the capital structure of a company, researchers studied firm-specific risks. L. Fisher [30] showed that the risk premium paid by companies is strongly associated with the levels of volatility exhibited by their profits. N. Baxter [31] writes that changes in company profit levels adversely affect the inclination to receive funding by means of debt. Therefore, companies are inclined to reduce financial distress costs, meaning that companies with relatively volatile potential money flows use less debts in their capital than those with more stable flows. Using the model which considers the bankruptcy costs tax shield, R. Castanias [32] ascertains the inverse relationship between business risk and debt load. He shows that with the existing marginal tax rate and the limiting function of default costs, higher business risks result in a decline of the debt load. M. Bradley et al. [33] consider the model of the capital structure over the same period in order to show the existence of inverse dependence between the optimal debt level and profits volatility.

Thus, the earlier papers considered those factors which are more characteristic of a certain company, instead of external factors which represent the specific character of the environment. Macroeconomic uncertainty was subsequently studied in greater detail. Gertler, Hubbard [34] showed that companies choose joint-stock capital options over debt capital options in periods of increased macroeconomic risk, in order to transfer at least a part of the risks from the creditors. C. Baum [35] demonstrated empirically that an increase in macroeconomic risk factors brings about a significant decrease of the optimal load of a long-term debt. D. Hatzinikolaou et al. [36] found out that uncertainty around inflation has a negative effect on the financial leverage of a company. H. Bhamra et al. [37] and H. Chen [38], using the dynamic capital structure approach, showed that unpredictable changes in macroeconomic conditions have a significant impact on companies' financing policy. In particular, $\mathrm{H}$. Chen [38] predicts that higher macroeconomic risks result in a decrease of the discounted value of the expected tax benefit. As long as the advantages of debt capital diminish, firms seek to reduce its amount when faced with financial hardships. H. Bhamra [37] points out that companies become more conservative (with regard to the use of debt financing) when economics is in an unfavourable state, in order to have financial flexibility. This implies a positive dependence upon financial leverage. M. Caglayan and A. Rashid [39] also show that macroeconomic risk is negatively associated with short-term debt in both public and non-public companies.
One may assume that uncertainty growth is contingent on the slowdown of the GDP growth rate. It should be noted that some papers studied the influence of business cycles on decisions about company financing [40]; [41]; [42]. However, there are serious differences between a business cycle and uncertainty. First, the business cycle and policy uncertainty influence the capital structure conceptually in different ways. The business cycle, in its essence, implies a change in the level of money flows - during boom periods money flows increase, and during recessionary periods they decrease. However, policy uncertainty can influence the debt load more through the demand and supply effect in reference to the debt capital. Although the policy uncertainty and business cycles may be correlated, each relates to different aspects of the economy. The business cycle represents the intensity of business operations and general productivity, while political uncertainty represents the role of the state in the economy's future behaviour [43]. In addition, S. Baker et al. [43] show that political uncertainty may be high not only during periods of economic contraction, but in boom periods as well.

In order to assess economic policy uncertainty, an index of economic policy uncertainty is used which was developed in 2012 by S. Baker et al. [43]. This index was made on the basis of a combination of three types of information: frequency of newspaper articles discussing economic uncertainty and the role of policy, the number of provisions of the federal tax code which were to cease to be effective in the coming years, and the degree of difference of economic forecasts as regards future inflation and future government expenditure for goods and services.

For Russia, the newspaper Kommersant is used. This newspaper is published every day all over the country and focuses mainly on economics and politics. In order to define the index, the number of articles which contain the terms "politics", "taxes", "costs", "regulation", "central bank", "law", and terms related to political institutions such as "Duma", "budget", etc. is calculated.

It should be noted that the index based on newspaper texts has a variety of advantages [43]. Other methods of calculating uncertainty (e.g. stock market volatility) are focused strongly on finance and shares while the index based on news represents uncertainty of policy in general, not just the capital market (which affects only public companies). An additional advantage of the news index is the fact that it may be expanded for application in many countries for a long period in the past.

There are two alternative channels [4] through which economic policy uncertainty may influence company financing, which are encompassed by the demand and supply effect. The fundamental idea of the demand and supply effect is that economic policy uncertainty deteriorates the external financing environment. When uncertainty grows, the information asymmetry between borrowers and lenders increases, and at the same time the future cash flows of companies are expected to be more volatile representing a higher risk of default. Both effects may result in higher costs of outside financing, and this, 
in turn, induces companies to reduce the debt load in order to obtain a greater financial flexibility. Recent research confirms these ideas. In particular, research focusing on the US financial market has demonstrated that economic policy uncertainty increases the risk premium for municipal bonds [44], incurs additional costs, and imposes more stringent terms on bank credits at the aggregate level as well as at a company level [45]. On the other hand, the demand effect implies the scenario when firms decrease their demand for funding in case of increased economic policy uncertainty. Research has demonstrated that when companies face uncertainty they are inclined to act in a more conservative way when taking investment decisions [46]; [9] and decrease their investments [47]; [48]; [49]. Thus, both channels should result in a negative dependence between economic policy uncertainty and company financial leverage.

At present there are only two empirical studies which consider the influence of economic policy uncertainty on the capital structure. W. Cao et al. [50] analyse 9,283 public and non-public companies in the USA between 1985 and 2011 and obtain a negative dependence between economic policy uncertainty and debt load. At the same time, the influence of uncertainty is lower for public companies. G. Zhang et al. [4], having studied 2,038 public companies in China and in identifying a negative dependent relationship between uncertainty and debt (joint, short-term and long-term debt), demonstrate that this relation is stronger in cases when a company is situated in regions of higher marketisation. Specifically, this was identified as being the case where the company is not partly owned by the government, and where the company has no stable relations with a bank at the time of the uncertainty increase.

This paper extends the existing, yet limited, empirical research of the influence of economic policy uncertainty on capital structure. Further, the scope is not merely extended from the point of view of the whole debt, but from the point of view of short-term and long-term debt separately. Our research differs from existing studies in its large sample size: the selection comprises observations of 16,882 Russian companies in the period covering 2000 to 2015.

The present paper is also interesting from the point of view of understanding how the influence of uncertainty varies with company-specific characteristic properties. First, it is expected that the sample size should mitigate against potential error effects for two reasons: major companies are more diversified and stable [51]; [52]; [53], and the largest Russian companies are very often of systemic national importance. As a result, in hard times the state supports such companies by target debt financing [27]; [16] as long as a considerable part of the banking system in Russia belongs to the state. Second, it is presumed that there are special economic sectors which will also be less exposed to the influence of the environment due to the strategic importance of their activity for the state, which will make the government use the banking system as a political tool to obtain some national goals [27]; [16].
These sectors are indicated in the list contained in 'Federal Law No. 57-FZ On the Procedure of Foreign Investment in Business Entities which are of Strategic Importance for National Defense and State Security', adopted by the State Duma and approved by the Federation Council on April 29,2008 . These sectors are those related to the nuclear power industry, weapons and military equipment, mass media etc.

\section{Hypotheses}

After an analysis of the relevant background academic literature, the following hypotheses were generated.

Hypothesis 1. Economic policy uncertainty has an adverse effect on the share of debt in the capital of companies.

Hypothesis 2. The influence of economic policy uncertainty on the share of short-term debt in the capital of major companies is less significant than for companies involved in activities of strategic importance for national defense and state security.

Hypothesis 3. The influence of economic policy uncertainty on the share of long-term debt in the capital of major companies is less significant than for companies involved in activities of strategic importance for national defense and state security.

\section{Data and Methodology}

Initially, we obtained data for 60,762 companies operating in Russia in all sectors (except for financial business). Then, the majority of these companies were deleted for the following reasons: 1) some companies were recorded in the database just notionally, they did not publish financial data; 2) many companies had large gaps in their data, e.g. intervals in publication of data of more than three years; 3 ) anomalous observations were identified and deleted (such values included return on assets results of less than 1 and more than 1 , asset tangibility values exceeding 1 , results where the ratio of capital expenditure to assets of less than 0 and more than 1.5, and risks values exceeding 1. Consequently 16,882 companies and 232,990 observations were analysed within the model.

The financial indicators of companies were uploaded from the information analysis system BIR-Analytic and the tested variables were calculated on the appropriate basis (see Table 1 below). 
Table 1. List of Tested Variables

\begin{tabular}{|c|c|c|}
\hline Variable & Description & Calculation formula \\
\hline \multirow{2}{*}{ Debttoass } & \multirow{2}{*}{ Financial leverage } & Liabilities \\
\hline & & $\overline{\text { Assets }}$ \\
\hline \multirow{2}{*}{ STDebttoass } & \multirow{2}{*}{ Short-term financial leverage } & Short - term liabilities \\
\hline & & Assets \\
\hline \multirow{2}{*}{ LTDebttoass } & \multirow{2}{*}{ Long-term financial leverage } & Long - term liabilities \\
\hline & & Assets \\
\hline \multirow{2}{*}{ ROA } & \multirow{2}{*}{ Profitability } & Net profit \\
\hline & & Assets \\
\hline \multirow{2}{*}{ Tangibility } & \multirow{2}{*}{ Asset tangibility } & $\underline{\text { Fixed assets }}$ \\
\hline & & Assets \\
\hline Revenue & Company size & $\operatorname{Ln}($ revenue $)$ \\
\hline \multirow{2}{*}{ TaxShield } & \multirow{2}{*}{ Tax shield } & Current income tax \\
\hline & & $\overline{\text { Income before tax }}$ \\
\hline \multirow{2}{*}{ NDTS } & \multirow{2}{*}{ Non-debt tax shield } & Depreciation \\
\hline & & Assets \\
\hline \multirow{2}{*}{ Capextoass } & \multirow{2}{*}{ Growth opportunity } & Capital costs \\
\hline & & Assets \\
\hline SDROA & Risks & Standard deviation ROA \\
\hline EPU & Economic policy uncertainty & Economic Policy Uncertainty Index \\
\hline Size & Dummy which characterises the company size & $\begin{array}{l}0 \text { - small business (revenue up to } 400 \\
\text { million rubles), } 1 \text { - medium business } \\
\text { (revenue from } 400 \text { million to } 1,000 \text { mil- } \\
\text { lion rubles), } 2 \text { - large business (revenue } \\
\text { over } 1,000 \text { million rubles) }\end{array}$ \\
\hline Important & $\begin{array}{l}\text { Dummy which characterises the importance of the } \\
\text { sector where the company operates }\end{array}$ & $\begin{array}{l}1 \text { - the company sector is on the list of } \\
\text { priority sectors, } 0 \text { - the company sector } \\
\text { is not on the list of priority sectors }\end{array}$ \\
\hline
\end{tabular}

Table 2 presents descriptive statistics of variables used in the model.

Table 2. Descriptive Statistics of Tested Variables

$\begin{array}{lcllll}\text { Variable (in the model) } & \text { Mean } & \begin{array}{l}\text { Standard } \\ \text { deviation }\end{array} & \text { Minimum } & \text { Median } & \text { Maximum } \\ \begin{array}{l}\text { Share of debt in the assets (Debt- } \\ \text { toass) }\end{array} & 0.4655 & 0.2834 & 0.00001 & 0.437131 & 0.9999 \\ \ldots \\ \begin{array}{l}\text { Share of long-term debt in the } \\ \text { assets (LTDebttoass) }\end{array}\end{array}$




\begin{tabular}{|c|c|c|c|c|c|}
\hline Variable (in the model) & Mean & $\begin{array}{l}\text { Standard } \\
\text { deviation }\end{array}$ & Minimum & Median & Maximum \\
\hline $\begin{array}{l}\text { Share of short-term debt in the } \\
\text { assets (STDebttoass) }\end{array}$ & 0.3907 & 0.2712 & 0.00001 & 0.340107 & 0.9999 \\
\hline Return on assets (ROA) & 0.0853 & 0.1119 & -0.9962 & 0.0562 & 0.9993 \\
\hline Asset tangibility (Tangibility) & 0.3194 & 0.2142 & $5.68 \mathrm{e}-07$ & 0.2927 & 0.9924 \\
\hline $\begin{array}{l}\text { Revenue (Revenue), thousand } \\
\text { rubles }\end{array}$ & $1,646,358$ & $28,200,000$ & 0 & 144,478 & $4,330,000,000$ \\
\hline Tax shield (TaxShield) & 0.2526 & 0.2234 & -0.9960 & 0.2359 & 0.9999 \\
\hline Non-debt tax shield (NDTS) & 0.0369 & 0.0315 & 0.0008 & 0.0305 & 0.9510 \\
\hline CapEx/Total Assets (Capextoass) & 0.0617 & 0.0979 & $1.369 \mathrm{e}-17$ & 0.0451 & 1.4801 \\
\hline Risk (SDROA) & 0.0776 & 0.1055 & 0.0001 & 0.0502 & 0.9943 \\
\hline EPU (EPU) & 114.9059 & 50.4323 & 56.4639 & 97.4196 & 232.6986 \\
\hline Dummy-size (Size) & 0.4243 & 0.7285 & 0 & 0 & 2 \\
\hline Dummy-importance (Important) & 0.1403 & 0.3473 & 0 & 0 & 1 \\
\hline
\end{tabular}

Figure 1. Index of economic policy uncertainty in Russia

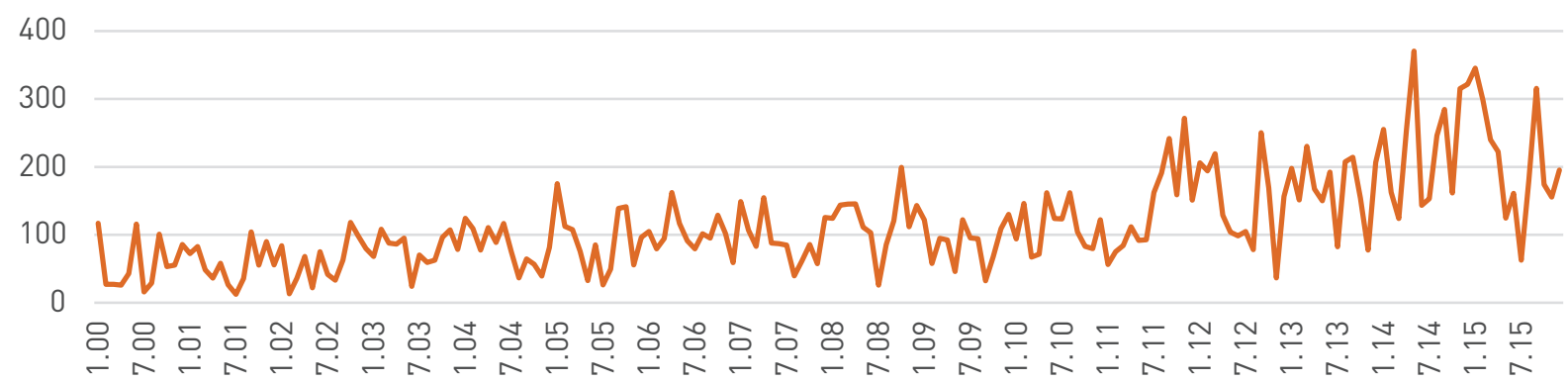

Source: 'Measuring Economic Policy Uncertainty' by Scott Baker, Nicholas Bloom and Steven J. Davis [43] at www. PolicyUncertainty.com. These data can be used freely with attribution to the authors, the paper, and the website.

Judging by median values, it may be noted that a typical company has a return on assets of about $5.6 \%$ and approximately $29.3 \%$ of fixed assets, and its revenue amounts to about 145 million rubles, i.e. it is a small company and its activity is of no strategic importance.

As regards the proportion of regions represented in the selection, one may note that traditionally the majority of companies are from Moscow, Moscow Region, and Saint-Petersburg.

As for the economic sectors, it may be noted that the top three as regards the number of companies are the agriculture, construction and food industries. The sector with the biggest number of companies in the selection of the sectors of strategic importance is Machinery and Equipment Manufacture. A large share (7-9\%) is also comprised by the following sectors: Metallurgical Production; Produc- tion of Vehicles, Trailers and Semitrailers; Extraction of Other Mineral Resources and Extraction of Metallic Ores. Altogether 2,363 companies are considered in the group of sectors of strategic importance.

The values of the economic policy uncertainty index were taken from the website 'http://www.policyuncertainty.com/' which updates monthly information for different countries including Russia. Figure 1 represents the values of the index for 2000-2017. Herewith we shall describe several peaks indicated in the diagram. In March of 2008, Dmitry Medvedev was elected president, in November of 2011 elections for the State Duma were carried out, in December of 2011 protests against violations in those elections took place, and in April of 2014 Crimea was annexed. Mean values for a year will be used in the model. 
In consideration of the foregoing, the following models will be used:

\section{Analysis of Influence on the Debt:}

$\operatorname{lnDebttoass}_{\text {it }}=\beta_{0}+\beta_{1} \cdot \ln$ ROA $_{\text {it }}+$

$+\beta_{2} \cdot \ln$ Tangibility $_{\text {it }}+\beta_{3} \cdot \ln$ Tax Shield $_{\text {it }}+$

$+\beta_{4} \cdot \operatorname{lnNDTS} \mathrm{S}_{\mathrm{it}}+\beta_{5} \cdot \operatorname{lnCapextoass}_{\mathrm{it}}+$

$+\beta_{6} \cdot \operatorname{lnSDROA}{ }_{\mathrm{it}}+\beta_{7} \cdot \operatorname{lnEPU} \mathrm{it}+$

$+\beta_{8} \cdot$ Size $\ln \mathrm{EPU}_{\mathrm{it}}+$

$+\beta_{9} \cdot$ Important $\bullet \operatorname{lnEPU} \mathrm{it}+\varepsilon_{\mathrm{it}}$.

Analysis of Influence on a Short-Term Debt:

$\operatorname{lnSTDebttoass}{ }_{\text {it }}=\beta_{0}+\beta_{1} \cdot \ln$ ROA $_{\text {it }}+$

$+\beta_{2} \cdot \ln$ Tangibility $_{\text {it }}+\beta_{3} \cdot \ln$ TaxShield $_{\text {it }}+$

$+\beta_{4} \cdot \operatorname{lnNDTS} \mathrm{it}_{\mathrm{it}}+\beta_{5} \cdot \operatorname{lnCapextoass}_{\mathrm{it}}+$

$+\beta_{6} \cdot \operatorname{lnSDROA}{ }_{\text {it }}+\beta_{7} \cdot \operatorname{lnEPU} \mathrm{it}+$

$+\beta_{8} \bullet$ Size $\bullet \operatorname{lnEPU} \mathrm{it}+\beta_{9} \cdot$Important$\cdot \operatorname{lnEPU} \mathrm{it}_{\mathrm{it}}+\varepsilon_{\mathrm{it}}$.

\section{Analysis of Influence on a Long-Term Debt:}

$\operatorname{lnLTDebttoass}_{\text {it }}=\beta_{0}+\beta_{1} \cdot \operatorname{lnROA}$ it +

$+\beta_{2} \cdot \ln$ Tangibility $_{\mathrm{it}}+\beta_{3} \cdot \ln$ Tax Shield $_{\mathrm{it}}+$

$+\beta_{4} \cdot \operatorname{lnNDTS} \mathrm{it}_{\mathrm{it}}+\beta_{5} \cdot \ln$ Capextoass $_{\mathrm{it}}+$

$+\beta_{6} \cdot \operatorname{lnSDROA}{ }_{\mathrm{it}}+\beta_{7} \cdot \operatorname{lnEPU} \mathrm{it}+$

$+\beta_{8} \bullet$ Size $\bullet \operatorname{lnEPU} \mathrm{it}+\beta_{9} \cdot$Important $\operatorname{lnEPU} \mathrm{it}_{\mathrm{it}}+\varepsilon_{\mathrm{it}}$.

To test the hypotheses we offer to consider three different methods: the Pool model (Pool), the fixed effect model (FE), and the random effect model (RE). In order to choose which model is the optimal one it is necessary to compare each model with each of the other applicable tests. The first test is the F-test which compares the Pool model with the fixed effect model. Using the Breusch-Pagan test we compare the RE-model to the Pool-model. Finally, we have to compare the FE-model to the RE-model. To conclude, we will compare the obtained models using the Hausman test.

\section{Results}

Table 3 presents the results of regressions demonstrating the significance level of coefficients.

Table 3. Results of the Pool-, FE- and RE-models

\begin{tabular}{|c|c|c|c|}
\hline & pool & $\mathrm{fe}$ & re \\
\hline & $\mathbf{b}$ & $\mathbf{b}$ & b \\
\hline $\ln \mathrm{ROA}$ & $-.1175006^{\star * *}$ & $-.0334549^{* * *}$ & $-.043996^{\star * *}$ \\
\hline lnTangibil $\sim y$ & $-.2604638^{\star * *}$ & $-.1456784^{* * *}$ & $-.1764622^{\star * *}$ \\
\hline lnTaxshield & $.0066822^{\star *}$ & - . 0021935 & .0024713 \\
\hline $\operatorname{lnNDTS}$ & $.042661^{\star * *}$ & $-.0494524^{\star \star *}$ & $-0256059^{\star * *}$ \\
\hline lnCapextoass & $.0725907^{\star \star *}$ & $.0302741^{\star * *}$ & $.0378073^{\star * *}$ \\
\hline $\operatorname{lnSDROA}$ & $-.0357645^{\star * \star}$ & $-.0324482^{\star * *}$ & $-.0391054^{\star * *}$ \\
\hline $\operatorname{lnEPU}$ & $-.101093^{\star * *}$ & $-.0751617^{\star * *}$ & $-.0664754^{\star * \star}$ \\
\hline SizelnEPU & $.0248238^{\star * \star}$ & $0035609^{* * *}$ & $0132428^{* * *}$ \\
\hline Importantl $\sim \mathrm{U}$ & $.0107861^{\star * *}$ & $.0417109^{\star}$ & .0016873 \\
\hline _cons & $-1.133745^{\star \star \star}$ & $-1.357252^{\star * *}$ & $-1.229487^{\star \star \star}$ \\
\hline
\end{tabular}

* $-0.05 ;{ }^{* *}-0.03 ;{ }^{* *}-0.01$.

In accordance with the tests (F-test, Breusch-Pagan Test, Hausman Test), results the best suited model is the fixed effect model. 


\section{Analysis of Influence on Short-Term Debt}

In the analysis procedure we will also consider three models: the Pool-model, the FE-model, and the RE-model. See table 4 for the results of regressions demonstrating the significance levels of coefficients.

Table 4. Results of Pool-, FE- and RE-models

\begin{tabular}{|c|c|c|c|}
\hline & pool & $\mathrm{fe}$ & re \\
\hline & b & b & b \\
\hline $\ln \mathrm{ROA}$ & $-.0747553^{\star \star \star}$ & $-.0171764^{\star \star \star}$ & $-.0227565^{\star * *}$ \\
\hline lnTangibil $\sim$ y & $-.3141624^{\star \star \star}$ & $-.1474417^{\star * \star}$ & $-.2078393^{\star * \star}$ \\
\hline lnTaxshield & $.1236264^{* * *}$ & $.0193636^{* * *}$ & $.0469793^{* * *}$ \\
\hline $\operatorname{lnNDTS}$ & $.0822277^{* * *}$ & $-.0197829^{* * *}$ & $.0108517^{\star *}$ \\
\hline lnCapextoass & $.0627566^{* * *}$ & $.0233829^{* * *}$ & $.0324626^{* * *}$ \\
\hline $\operatorname{lnSDROA}$ & $-.0308922^{\star * \star}$ & $-.0259012^{* * *}$ & $-.0322001^{* * *}$ \\
\hline $\operatorname{lnEPU}$ & -.0353115 & $-.0821978^{* * *}$ & $-.0569255^{* * *}$ \\
\hline SizelnEPU & $.0159407^{* * *}$ & $.0064483^{* * *}$ & $.0136829^{* * *}$ \\
\hline Importantl $\sim \mathrm{U}$ & $.0080359^{* * *}$ & .0370562 & -.0058707 \\
\hline _cons & $-1.275815^{\star \star \star}$ & $-1.369286^{* * *}$ & $-1.271673^{\star \star \star}$ \\
\hline
\end{tabular}

${ }^{*}-0.05 ;{ }^{* *}-0.03 ;{ }^{* *}-0.01$.

In accordance with the tests (F-test, Breusch-Pagan Test, Hausman Test), results the best suited model is the fixed effect model.

\section{Interpretation of the Obtained Results}

In table 5 one may see the results of building the final regression models for three types of debt. The share of explained variance amounts to $10-14 \%$.

Table 5. Results of the Models for Three Types of Debt

\begin{tabular}{|c|c|c|c|}
\hline & total & short term & long term \\
\hline $\operatorname{lnROA}$ & $-.0355014^{* * *}$ & $-.0171969^{* * *}$ & $-.1365615^{\star * *}$ \\
\hline lnTangibil y & $-.1479721^{* * *}$ & $-.1474558^{* * *}$ & $3315116^{* * *}$ \\
\hline $\operatorname{lnNDTS}$ & $-.0439151^{\star * \star}$ & $-.0198276^{* * *}$ & $-.0401693^{\star *}$ \\
\hline $\operatorname{lnCapextoass}$ & $.0315367^{* * *}$ & $.0233574^{* * *}$ & $.0294664^{* * *}$ \\
\hline $\operatorname{lnSDROA}$ & $-.0261268^{* * *}$ & $-.0258868^{\star * *}$ & $-.0511072^{\star * *}$ \\
\hline $\operatorname{lnEPU}$ & $-.0670104^{* \star *}$ & $-.0508521^{\star * *}$ & $-.0875061^{\star}$ \\
\hline SizelnEPU & $.0038217^{* * *}$ & $.0064148^{* * *}$ & $.0280613^{\star * *}$ \\
\hline Importantl $\sim \mathrm{U}$ & $.0405915^{\star}$ & & $.0162739^{*}$ \\
\hline lnTaxshield & & $.019315^{\star * \star}$ & $-.2080167^{\star * \star}$ \\
\hline _cons & $-1.365111^{\star \star \star}$ & $-1.368992^{\star * *}$ & $-4.393502^{\star * \star}$ \\
\hline r2_b & .1023349 & .1303846 & .1372527 \\
\hline
\end{tabular}


Out of the three presented hypotheses, only hypothesis 2 was not confirmed. This related to the less significant influence of economic policy uncertainty on the short-term debt leverage for companies of strategic importance.

Each factor is hereby considered individually.

ROA - profitability. The results correspond to the pecking order theory, which holds that if a company has enough internal funds for financing, it will not use debt capital. The obtained relation corresponds to the empirical studies [54]; [55]; [56]; [57], [58].

Tangibility - tangibility of assets. The negative dependence of joint debt and short-term debt corresponds to the pecking order theory which holds that a company owning sufficient tangible assets generates by itself enough money to finance its activity. The other direction of influence on short-term debt confirms the researches of Hall et al. [59]. Yet another direction of influence on long-term debt confirms the studies by both Hall et al. [59] and F. Sogorb-Mira [60] which found out that short-term debt is negatively associated with asset tangibility, and long-term debt is positively associated with it. It may be related to the fact that as a rule long-term debt is used to finance large-scale projects and big capital expenditures, while short-term debt is used for financing short-term assets, and asset tangibility pertains to the share of fixed assets. As long as the companies in the selection have more short-term debt the influence of tangibility on joint debt is the same as on short-term debt.

Taxshield - tax shield. This factor turned out to be significant for long-term and short-term debt, (and what is more, this holds true with different signs), while for joint debt the relation turned out to be insignificant. Absence of a significant coefficient for joint debt is probably related to the fact that the sign of dependence on the tax shield is different for short-term and long-term debt, and as a result this makes the joint debt behaviour ambiguous. The positive dependence of short-term debt and tax shield corresponds to the trade-off theory, which holds that the more the effective tax rate, the more companies borrow in order to create a tax shield. As judged by the results, only short-term debt is used to create the tax shield, probably due to an easier access to such debt. At the same time, long-term debt is a more complex financial product, therefore it is not used for these purposes. The authors who have identified a negative relationship [61]; [62]; [60], in studying small and medium-sized enterprises explain that these enterprises are less profitable, and consequently, more risky. That can bring about a set of circumstances whereby high tax rates result in additional diminishing of profits and a reluctance to borrow. It should be noted that the selection used for analysis in this paper also mainly consists of small and medium-sized enterprises.

NDTS - non-debt tax shield. In accordance with the trade-off theory non-debt tax benefits have a negative effect on debt load, and the results in this study corresponds to the theory. When companies gain non-debt benefits they abnegate the debt-related ones. The obtained relations confirm previous empirical studies, as regards the aggregate capital [54]; [63], and as regards short-term and long-term debts [60].

Capextoass - growth opportunity. The obtained coefficients correspond to the pecking order theory and a number of empirical studies [64]; [65]; [66]; [60]. It means that companies with great growth opportunities tend to get more debt financing to satisfy their needs in terms of growth, i.e. in order to grow more and to use money for capital expenditure it is necessary to have access to sufficient funds.

SDROA - risks. The obtained result corresponds to the pecking order theory and empirical studies [33]; [67]; and [68]. The riskier the company is, the lesser its debt load. This may be due to the fact that creditors are not inclined to jeopardise the safety of repayments of their money. EPU - economic policy uncertainty. The obtained result corresponds to previous studies [50]; [4]. In periods of uncertainty, companies do not chance taking credits due to the risk of difficulties of repayment, while creditors are not inclined to risk granting loans, thus jeopardising their repayment.

Important ${ }^{\star} \mathrm{EPU}$ - the influence of companies' activity on the influence of economic policy uncertainty. The positive coefficient (which is opposite to the influence of economic policy uncertainty), may be related to the fact that nearly half of the banking system belongs to the state, which makes banks a political tool, because, if necessary, the state may allocate funds to target sectors for support [27]; [28]. However, such influence was not confirmed for short-term debt, and this is probably related to the fact that state support is mainly provided as long-term debt, thus affecting joint debt as well.

Size EPU - the effect of a company's size on the influence of economic policy uncertainty. The positive coefficient opposite to the influence of economic policy uncertainty may be related to the fact that large companies are more stable [51]; [52]; [53]. The result is that creditors risk less when financing them by means of debt. As long as the influence of the sector's importance on the influence of uncertainty on short-term debt has not been confirmed it is fair to assume that the influence of size is not related to the support granted to them by the state. Otherwise, if that is the case, the influence on short-term debt for the size and importance would have been the same.

\section{Conclusion}

Determinants of capital structure are a key issue in the theory of capital structure. In this paper the influence of traditional factors on the capital structure formation was verified and in general the results of previous studies were confirmed.

Using the index of economic policy uncertainty calculated in 2012, we studied the influence of economic policy uncertainty on the debt load level of 16,882 Russian 
companies in the period from 2000 to 2017. The applied uncertainty measure unifies all elements which previously have been tested separately, thus summing up the previous studies concerning the negative influence of uncertainty on debt load. Moreover, it was shown that as long as a significant state participation is characteristic of the Russian banking system, the offer of debt financing is different for various sectors (i.e. the sectors which are of importance for the state are supported in troubled economic periods). However, this influence is nonexistent for the short-term debt leverage. This is probably due to the fact the state supports companies in hard times by means of long-term credits, thus enabling a company to be stable for the near future. The influence of uncertainty is also less significant for major companies as regards all types of debt which, by all appearances, is related to their greater stability and posing less risks for creditors.

An understanding of these interrelations may be useful to company managers and investors who could understand better what will happen to a company when uncertainty in the market increases or decreases. This is particularly true for those operating in fluctuating markets of developing or transitional economies.

At present it is not clear whether the influence of uncertainty on companies of strategic importance is mitigated due to sector-specific character or state participation. In other words, if the majority of companies of a strategically important sector are state-owned, it is the state participation which produces the dominant effect, not the specific character of the sector. Therefore, in future it may be worthwhile to include a dummy variable in the model which is responsible for representing the presence of state ownership in company capital simultaneously with the sectors of strategic importance.

A noteworthy detail in consideration of the process of this study, is that improvement of discipline in Russian companies as regards submitting financial reports could have enabled us to have a larger selection, as well as the fact that an unbalanced panel might have corrupted or displaced the evaluations.

\section{References}

1. Modigliani F., Miller M.H. The cost of capital, corporation finance and the theory of investment. The American Economic Review. 1958;48(3):261297.

2. Ramli N.A., Latan H., Solovida G.T. Determinants of capital structure and firm financial performance - A PLS-SEM approach: Evidence from Malaysia and Indonesia. Quarterly Review of Economics and Finance. 2019;71:148-160. DOI: 10.1016/j. qref.2018.07.001

3. Vo X.V. Determinants of capital structure in emerging markets: Evidence from Vietnam. Research in International Business and Finance. 2017;40:105113. DOI: 10.1016/j.ribaf.2016.12.001
4. Zhang G., Han J., Pan Z., Huang H. Economic policy uncertainty and capital structure choice: Evidence from China. Economic Systems. 2015;39(3):439-457. DOI: 10.1016/j.ecosys.2015.06.003

5. Blažková I., Dvouletý O. Investigating the differences in entrepreneurial success through the firmspecific factors: Microeconomic evidence from the Czech food industry. Journal of Entrepreneurship in Emerging Economies. 2019;11(2):154-176. DOI: 10.1108/JEEE-11-2017-0093

6. Mursalim, Mallisa, M., Kusuma, H. Capital structure determinants and firms' performance: Empirical evidence from Thailand, Indonesia and Malaysia. Polish Journal of Management Studies. 2017;16(1):154164. DOI: 10.17512/pjms.2017.16.1.13

7. Kumar S., Colombage S., Rao P. Research on capital structure determinants: a review and future directions. International Journal of Managerial Finance.2017;13(2):106-132. DOI: 10.1108/IJMF-092014-0135

8. Baker S.R., Bloom N., Davis S.J. Has economic policy uncertainty hampered the recovery? 2012. URL: http://www.policyuncertainty.com/media/HasEcono micPolicyUncertaintyHamperedRecovery.pdf

9. Bloom N., Bond S., Van Reenen J. Uncertainty and investment dynamics. The Review of Economic Studies. 2007;74(2):391-415. DOI: 10.1111/j.1467937X.2007.00426.x

10. Bloom N. The impact of uncertainty shocks. Econometrica, 2009;77(3):623-685. DOI: 10.3982/ ECTA6248

11. Anoshkina E.S., Markovskaya E.I. Empirical analysis of capital structure determinants of Russian oil and gas companies. Ekonomicheskaya politika = Economic Policy. 2018;13(5):80-109. (In Russ.). DOI: 10.18288/1994-5124-2018-5-80-109

12. Belkhir M., Maghyereh A., Awartani B. Institutions and corporate capital structure in the MENA region. Emerging Markets Review. 2016;26:99-129. DOI: 10.1016/j.ememar.2016.01.001

13. Bevan A.A., Danbolt J. Capital structure and its determinants in the UK - a decompositional analysis. Applied Financial Economics. 2002;12(3):159-170. DOI: 10.1080/09603100110090073

14. La Rocca M., La Rocca T., Cariola A. Capital structure decisions during a firm's life cycle. Small Business Economics. 2011;37(1):107-130. DOI: $10.1007 / \mathrm{s} 11187-009-9229-\mathrm{Z}$

15. Chakraborty I. Capital structure in an emerging stock market: The case of India. Research in International Business and Finance. 2010;24(3):295-314. DOI: 10.1016/j.ribaf.2010.02.001

16. Delcoure N. The determinants of capital structure in transitional economies. International Review of Economics \& Finance. 2007;16(3):400-415. DOI: 10.1016/j.iref.2005.03.005 
17. Wu L., Yue H. Corporate tax, capital structure, and the accessibility of bank loans: Evidence from China. Journal of Banking \& Finance. 2009;33(1):30-38. DOI: 10.1016/j.jbankfin.2006.10.030

18. Céspedes J., González M., Molina C.A. Ownership and capital structure in Latin America. Journal of Business Research. 2010;63(3):248-254. DOI: 10.1016/j.jbusres.2009.03.010

19. Rajagopal S. The portability of capital structure theory: Do traditional models fit in an emerging economy? Journal of Finance and Accountancy. 2010;5:1-17.

20. Lopes A.B., de Alencar R.C. Disclosure and cost of equity capital in emerging markets: The Brazilian case. The International Journal of Accounting. 2010;45(4):443-464. DOI: 10.1016/j. intacc.2010.09.003

21. Nivorozhkin E. Capital structures in emerging stock markets: The case of Hungary. The Developing Economies. 2002;40(2):166-187. DOI: 10.1111/j.17461049.2002.tb01006.x

22. Danilov P.V. Capital structure forming factors of Russian and Ukrainian companies. Zhurnal ekonomicheskoi teorii = Russian Journal of the Economic Theory. 2007;(4):145-160. (In Russ.).

23. Ivanov I. Capital structure determinants of Russian public companies. Korporativnye finansy = Journal of Corporate Finance Research. 2010;4(1):5-38. DOI: 10.17323/j.jcfr.2073-0438.4.1.2010.5-38

24. Ivashkovskaya I.V., Makarov P.V. Do companies from emerging markets follow classic theories of capital structure choice? Empirical study on companies from Central and Eastern Europe. Korporativnye finansy = Journal of Corporate Finance Research. 2010;4(3):4762. DOI: 10.17323/j.jcfr.2073-0438.4.3.2010.47-62 (In Russ.).

25. Ivashkovskaya I.V., Solntseva M.S. Capital structure in Russian companies as a strategic decision. Vestnik Sankt-Peterburgskogo universiteta. Menedzhment = Vestnik of Saint Petersburg University. Management Series. 2008;(3):3-32. (In Russ.).

26. Pöyry S., Maury B. Influential ownership and capital structure. Managerial and Decision Economics. 2010;31(5):311-324. DOI: 10.1002/mde.1477

27. La Porta R., Lopez-de-Silanes F., Shleifer A. Government ownership of banks. The Journal of Finance. 2002;57(1):265-301. DOI: 10.1111/15406261.00422

28. Vernikov A. Corporate governance and control in Russian banks. MPRA Paper. 2008;(10028). URL: https://mpra.ub.uni-muenchen.de/10028/1/MPRA_ paper_10028.pdf

29. Faccio M. Politically connected firms. The American Economic Review. 2006;96(1):369-386. DOI: $10.1257 / 000282806776157704$
30. Fisher L. Determinants of risk premiums on corporate bonds. Journal of Political Economy. 1959;67(3):217-237. DOI: 10.1086/258172

31. Baxter N.D. Leverage, risk of ruin and the cost of capital. The Journal of Finance. 1967;22(3):395-403. DOI: 10.1111/j.1540-6261.1967.tb02975.x

32. Castanias R. Bankruptcy risk and optimal capital structure. The Journal of Finance. 1983;38(5):16171635. DOI: $10.2307 / 2327591$

33. Bradley M., Jarrell G.A., Kim E. On the existence of an optimal capital structure: Theory and evidence. The Journal of Finance. 1984;39(3):857-878. DOI: 10.1111/j.1540-6261.1984.tb03680.x

34. Gertler M., Hubbard R.G. Corporate overindebtedness and macroeconomic risk. Columbia University. 1991. Mimeograph.

35. Baum C.F., Stephan A., Talavera O. The effects of uncertainty on the leverage of nonfinancial firms. Economic Inquiry. 2009;47(2):216-225. DOI: 10.1111/j.1465-7295.2007.00116.x

36. Hatzinikolaou D., Katsimbris G.M., Noulas A.G. Inflation uncertainty and capital structure: Evidence from a pooled sample of the Dow-Jones industrial firms. International Review of Economics \& Finance. 2002;11(1):45-55. DOI: 10.1016/S10590560(01)00085-5

37. Bhamra H.S., Kuehn L.-A., Strebulaev I.A. The aggregate dynamics of capital structure and macroeconomic risk. The Review of Financial Studies. 2010;23(12):4187-4241. DOI: 10.1093/rfs/ hhq075

38. Chen H. Macroeconomic conditions and the puzzles of credit spreads and capital structure. The Journal of Finance. 2010;65(6):2171-2212. DOI: 10.1111/j.15406261.2010.01613.x

39. Caglayan M., Rashid A. The response of firms' leverage to risk: Evidence from UK public versus nonpublic manufacturing firms. Economic Inquiry. 2014;52(1), 341-363. DOI: 10.1111/ecin.12042

40. Choe H., Masulis R.W., Nanda V. Common stock offerings across the business cycle: Theory and evidence. Journal of Empirical Finance. 1993;1(1):331. DOI: 10.1016/0927-5398(93)90003-A

41. Korajczyk R.A., Levy A. Capital structure choice: Macroeconomic conditions and financial constraints. Journal of Financial Economics. 2003;68(1):75-109. DOI: 10.1016/S0304-405X(02)00249-0

42. Erel I., Julio B., Kim W., Weisbach M.S. Macroeconomic conditions and capital raising. The Review of Financial Studies. 2012;25(2):341-376. DOI: 10.1093/rfs/hhr085

43. Baker S.R., Bloom N., Davis S.J. Measuring economic policy uncertainty. NBER Working Paper. 2015;(21633). URL: https://www.nber.org/papers/ w21633.pdf 
44. Gao P., Qi Y. Political uncertainty and public financing costs: Evidence from US municipal bond markets. SSRN Electronic Journal. 2012. DOI: $10.2139 /$ ssrn. 2024294

45. Francis B.B., Hasan I., Zhu Y. Political uncertainty and bank loan contracting. Journal of Empirical Finance. 2014;29:281-286. DOI: 10.1016/j. jempfin.2014.08.004

46. Bernanke B.S. Irreversibility, uncertainty, and cyclical investment. The Quarterly Journal of Economics. 1983;98(1):85-106. DOI: 10.2307/1885568

47. Kang W., Lee K., Ratti R.A. Economic policy uncertainty and firm-level investment. Journal of Macroeconomics. 2014;39A:42-53. DOI: 10.1016/j. jmacro.2013.10.006

48. Gulen H., Ion M. Policy uncertainty and corporate investment. The Review of Financial Studies. 2016;29(3):523-564. DOI: 10.1093/rfs/hhv050

49. Wang Y., Chen C.R., Huang Y.S. Economic policy uncertainty and corporate investment: Evidence from China. Pacific-Basin Finance Journal. 2014;26:227243. DOI: 10.1016/j.pacfin.2013.12.008

50. Cao W., Duan X., Uysal V.B. Does political uncertainty affect capital structure choices? University of Oklahoma Working Paper. 2013. URL: https://editorialexpress.com/cgi-bin/conference/ download.cgi?db_name=CICF2014\&paper_id=693

51. Warner J.B. Bankruptcy, absolute priority, and the pricing of risky debt claims. Journal of Financial Economics. 1977;4(3):239-276. DOI: 10.1016/0304405X(77)90002-2

52. Ang J.S., Chua J.H., McConnell J.J. The administrative costs of corporate bankruptcy: A note. The Journal of Finance. 1982;37(1):219-226. DOI: 10.1111/j.15406261.1982.tb01104.x

53. Pettit R.R., Singer R.F. Small business finance: A research agenda. Financial Management. 1985;14(3):47-60. DOI: 10.2307/3665059

54. Titman S., Wessels R. The determinants of capital structure choice. The Journal of Finance. 1988;43(1):119. DOI: $10.2307 / 2328319$

55. Kester W.C. Capital and ownership structure: A comparison of United States and Japanese manufacturing corporations. Financial Management. 1986;15(1):5-16. DOI: 10.2307/3665273

56. Friend I., Hasbrouck J. Determinants of capital structure. In: Chen A., ed. Research in finance. Vol. 7. New York: JAI Press;1988:1-19.

57. Friend I., Lang L.H.P. An empirical test of the impact of managerial self-interest on corporate capital structure. The Journal of Finance. 1988;43(2):271-281. DOI: $10.2307 / 2328459$
58. Gonedes N.J., Dopuch N. Analysis of financial statements: Financial accounting and the capital market. Sarasota, FL: American Accounting Association; 1989.

59. Hall G.C., Hutchinson P.J., Michaelas N. Determinants of the capital structures of European SMEs. Journal of Business Finance \& Accounting. 2004;31(5-6):711-728. DOI: 10.1111/j.0306686X.2004.00554.x

60. Sogorb-Mira F. How SME uniqueness affects capital structure: Evidence from a 1994-1998 Spanish data panel. Small Business Economics. 2005;25(5):447-457. DOI: $10.1007 / \mathrm{s} 11187-004-6486-8$

61. Jordan J., Lowe J., Taylor P. Strategy and financial policy in UK small firms. Journal of Business Finance \& Accounting. 1998;25(1-2):1-27. DOI: 10.1111/14685957.00176

62. Michaelas N., Chittenden F., Poutziouris P. Financial policy and capital structure choice in UK SMEs: Empirical evidence from company panel data. Small Business Economics. 1999;12(2):113-130. DOI: 10.1023/A:1008010724051

63. Fama E.F., French K.R. Testing trade-off and pecking order predictions about dividends and debt. The Review of Financial Studies. 2002;15(1):1-33. DOI: 10.1093/rfs/15.1.1

64. Psillaki M., Mondello G. Financing small and medium sized firms: Coordination and transaction costs. Cahiers Monnaie et financement. 1996;(24):4770 .

65. Acs Z.J., Isberg S.C. Capital structure, asset specificity, and firm size: A transaction cost analysis. In: Helmstadter E., Perlman M., eds. Behavioral norms, technological progress, and economic dynamics. Ann Arbor, MI: The University of Michigan Press; 1996:285-298.

66. Beck T., Demirguc-Kunt A. Small and medium-size enterprises: Access to finance as a growth constraint. Journal of Banking \& Finance. 2006;30(11):29312943. DOI: 10.1016/j.jbankfin.2006.05.009

67. MacKie-Mason J.K. Do taxes affect corporate financing decisions? The Journal of Finance. 1990;45(5):1471-1493. DOI: 10.2307/2328746

68. Wald J.K. How firm characteristics affect capital structure: An international comparison. The Journal of Financial Research. 1999;22(2):161-187. DOI: 10.1111/j.1475-6803.1999.tb00721.x 